\title{
JAN PAWEŁ II JAKO NAUCZYCIEL MARIOLOGII I MARYJNOŚCI*
}

\author{
JOHN PAUL II AS A TEACHER OF MARIOLOGY \\ AND MARIAN DEVOTION
}

\begin{abstract}
A b s t r a c t. According to the methodological principle, the correct interpretation of John Paul II (not only him) suggests taking into account the broader context of his statements. In the presentation of the Pope's Mariology and Marian devotion, he focuses on what is more or less astonishing. John Paul II used the "Treaty" of St. Louis Grignion de Montfort. He never argued with him, never criticized him, but he did not take over everything. John Paul II consistently teaches the Mariology of Vatican II, not the Mariology of Grignion; strongly promotes the prayer of the rosary, incl. in Rosarium Virginis Mariae, but calls for contemplation of the Mysteries of our faith, which are recalled in it; she appeals and asks people not to be satisfied with simply pray the Rosary.
\end{abstract}

Key words: Mariology of John Paul II; Masters and Doctorate degrees in Mariology of John Paul II; mercy (bibliography); Napiórkowski S.C. on the Mariology of John Paul II.

Podejmujemy od wielu lat trudny i ważny problem spotkania Różańca z Koronką do Miłosierdzie Bożego i S. Faustyną. Co z miłosierdziem Bożym w Różańcu? Czy go tam nie za mało, że Niebo zaleca nam Koronkę do Miłosierdzia Bożego?

Do współmyślenia z nami, do wsparcia naszych poszukiwań ośmielam się zaprosić Jana Pawła II

Prof. dr hab. Stanislaw Celestyn Napiórkowski OFMConv KUL, UKSW, Kolbianum, Niepokalanów; e-mail: c.napiorkowski@gmail.com; ORCID: http://orcid.org/0000-0002-3389-9118.

* Artykuł na podstawie referatu wygłoszony podczas konferencji teologicznej „Rosarium misericordiae" (KUL, 29 października 2019 roku). 


\section{ZADZIWIENIA MARIOLOGIĄ I MARYJNOŚCI Ą JANA PAWŁA II}

Wielokrotnie zabierałem głos na temat mariologii i maryjności naszego Papie$\dot{z ̇ a}{ }^{2}$. Może najpełniej zaproponowałem ich charakterystykę w Radio eR Lublin. Mówiłem o swoich zadziwieniach mariologią Jana Pawła (bo też jest się czym zadziwiać. Przypomnę króciutko. Bliżej zainteresowani bez trudu znajdą tekst w mojej książce Oto Ja, Stużebnica Pana) ${ }^{3}$.

Zachwycony jestem Matką naszego Pana i podziwiam naszego Jana Pawła II. Postanowiłem dzielić się swoimi zadziwieniami. Bo też jest czym się zadziwiać, słuchając naszego papieża. Wsłuchując się w to, co mówił, i czytając, co pisał o Matce Pana, odnotowałem 18 zadziwień. Zapraszam do zadziwiania się ze mną. Na koniec przeglądu zadziwień przesuwam dwa zadziwienia wyraźnie wiążące się z naszym problemem.

\section{CZTERY ZADZIWIENIA ENCYKLIKĄ REDEMPTORIS MATER}

Pierwsze zadziwienie mariologiczną encykliką Jana Pawła II. Zadziwienie, ponieważ ta encyklika nie była pierwszą jego encykliką. Przecież papież maryjny jako hasło obrał Totus tuus - 'cały Twój'. Można było oczekiwać, że pierwszą jego encykliką będzie encyklika mariologiczna. Tymczasem encyklika mariologiczna nie była ani pierwsza, ani druga, ani nawet trzecia, a dopiero szósta. Najpierw była encyklika „Odkupiciel człowieka” - Redemptor hominis, a więc o Chrystusie Panu, naszym Odkupicielu i odkupionym człowieku (temat odkupionego człowieka dość wyraźnie dominuje nad tematem Chrystusa Odkupiciela). Drugą była encyklika o Bogu bogatym w miłosierdzie - Dives in misericordia Deus, a więc o Bogu Ojcu. Trzecią była encyklika o Duchu Świętym - Spiritum et vivificantem. Prawdopodobnie niektórzy pobożni czciciele Matki Bożej byli zawiedzeni. Ja jako teolog byłem cały w skowronkach. $\mathrm{Z}$ teologicznego punktu widzenia tak właśnie być powinno. Wszystko na swoim miejscu. Najpierw wielka trylogia o Bogu w Trójcy, a dopiero potem cała reszta świata z Matką naszego Pana na czele.

Drugie zadziwienie - świeże ujęcie nauki o pośrednictwie Matki Bożej. Obok modelu przez Maryję do Chrystusa, pośrednictwo Maryi w Chrystusie, a także pośrednictwo Maryi w Duchu Świętym.

${ }^{2}$ Zob. bibliografię na końcu artykułu.

3 S.C. NAPIóRKowski, Oto Ja, Stużebnica Pana (problemy - poszukiwania - perspektywy), Lublin 2015, s. 339-350. 
Trzecie zadziwienie encykliką - piękny tekst o Abrahamowej wierze Maryi. Maryja w zwiastowaniu uwierzyła w rzecz wprost nieprawdopodobną. Ta Jej wiara - jak wiara Abrahama - miała znaczenie gigantyczne, dziejozbawcze. Nie była to Jej prywatna sprawa.

Czwarte zadziwienie - brak tytułu „współodkupicielka”. Papież pisał encyklikę w czasie olbrzymiego nacisku na ogłoszenie dogmatu o Maryi współodkupicielce. Milczenie autora encykliki jest więc wymowne, więcej, to milczenie krzyczy, woła, zobowiązuje... Nie ma też w encyklice maryjnego papieża tytułu „Wszechpośredniczka łask” czy „pośredniczka łask wszelkich”. Mamy obowiązek czytać także to, czego w encyklice nie ma, choć mogło być, a nawet wydawało się, że z pewnością będzie.

\section{DWA ZADZIWIENIA RÓŻAŃCOWE}

Jan Paweł II wydał List apostolski Rosarium Virginis Mariae do biskupów, duchowieństwa i wiernych o różańcu świętym (16 października 2002). Pierwsze zadziwienie różańcem - historyczna rewolucja w pobożności maryjnej: dodanie całej nowej części (Tajemnice Światła). Słyszałem, że już papieżowi Pawłowi VI proponowano takie poszerzenie obszaru różańcowych tajemnic, ale tamten papież nie odważył się naruszyć tradycyjnej formuły trzech części. Wspaniale, że Jan Paweł II włączył do różańca pięć nowych tajemnic: chrzest Chrystusa w Jordanie, objawienie się Chrystusa na weselu w Kanie, głoszenie Królestwa Bożego i wzywanie do nawrócenia, przemienienie na Górze Tabor i ustanowienie Eucharystii.

Od dawna marzyłem o dołączeniu do różańca nowych tajemnic wiary. List apostolski o różańcu ukazał się w 2002 roku. 6 lat wcześniej, w 1996 roku w wydawnictwie Więź w Warszawie ukazała się książka Dzieci Soboru zadaja pytania. W tej książce znalazł się obszerny wywiad ze mną przeprowadzony przez dwie panie (obie moje doktorki): Elę Adamiak (dziś po habilitacji na Wydziale Teologii Uniwersytetu Adama Mickiewicza w Poznaniu) i Monikę Waluś (dziś po doktoracie z teologii, w drodze do habilitacji). Znalazłem tam taką oto swoją wypowiedź:

Różaniec to piękna i bardzo tradycyjna modlitwa; byłaby jeszcze piękniejsza i jeszcze bardziej ewangeliczna, gdyby w każdej tajemnicy miała dziesięć Ojcze nasz i jedno Zdrowaś Maryjo... Nota bene: dlaczego nie ma w różańcu tajemnic: „Chrzest 
Jezusa w Jordanie”, „Powołanie Apostołów”, „Przemienienie”, „Ustanowienie świętej Eucharystii”, „Powtórne przyjście Chrystusa”?4

Bardzo mi brakuje w różańcu tajemnicy ucieczka do Egiptu. Jakżeż to aktualne poprzez stulecia: migracja, emigracja, ucieczki z własnego kraju wobec prześladowań, bezrobocia, Pan Jezus w Egipcie, a więc w Afryce, także Matka Boża na tamtym kontynencie...

Mój przyjaciel, profesor teologii oraz biskup, zauważył jeszcze coś, co prawdopodobnie należałoby zmienić w odmawianiu różańca, zwłaszcza coram Sanctissimo, przed wystawionym Najświętszym Sakramentem. Ewangelia pozostawiła nam jedną jedyną modlitwę Maryi i nie ma jej w różańcu! Wspomniany przyjaciel powiedział:

Podczas sympozjum na temat Rosarium Virginis Mariae powstała kwestia, czy w swej refleksji o różańcu, a zwłaszcza w swej propozycji bardziej kontemplatywnego odmawiania go, Jan Paweł II nie zatrzymał się w połowie drogi, ponieważ pozostało zawołanie „Święta Maryjo, Matko Boża, módl się za nami [...]” jako forma modlitwy wstawienniczej. Rodzi się tu pytanie, czy nie trzeba, zwłaszcza w sanktuariach maryjnych, odważyć się na to, aby zamiast „Święta Maryjo, Matko Boża” wymawiać słowa biblijne, np. słowa Magnificat: „Wielbi dusza moja Pana i raduje się duch mój, w Bogu Zbawicielu moim. Amen" (może nie codziennie, ale chociażby od czasu do czasu). [...] Jeśli w centrum uwagi jest Jezus, a nie ulega wątpliwości, że tak jest, to taka forma kontemplacji, zwłaszcza przy wystawieniu Przenajśw. Sakramentu, byłaby kontemplowaniem wraz z Maryją oblicza Chrystusowego ${ }^{5}$.

Solidaryzuję się z tym głosem. Trudno wprost usprawiedliwić naszą praktykę: wystawiamy Przenajświętszy Sakrament, a więc Pana Jezusa, i odmawiamy przed nim różaniec, a w nim powtarzamy po wielekroć prośbę do Matki Bożej, by się za nami modliła. Gdybyśmy klęczeli przed figurą Matki Bożej..., ale klęczymy przed Panem Jezusem i powtarzamy prośbę do Matki Bożej, by Ona za nami do Niego... A On tego słucha i dziwi się, czemu tak, a nie wprost do Niego... A przecież on pozostawił nam jasną swoją katechezę o modlitwie:

${ }^{4}$ Z. Nosowski (red.), Dzieci Soboru zadaja pytania. Rozmowy o Soborze Watykańskim II, Warszawa 1996, s. 106-107.

5 A. Czaja, Głos w Panelu duszpasterskim. Papieska mariologia na dziś Recepcja mariologii Jana Pawła II w polskich sanktuariach, w: S.C. NAPIóRKowski, K. Pex (red.), Mariologia Jana Pawta II. Problem interpretacji - sposób recepcji, Lublin 2007; NAPIÓRKowsKI, Oto Ja, Stużebnica Pana, s. 122-127, 341. 
„Przyjdźcie do Mnie wszyscy, którzy utrudzeni i obciążeni jesteście, a Ja was pokrzepię" (Mt 11,28).

Drugie zadziwienie różańcowe: Jan Paweł II bardzo gorąco zaleca kontemplację w Różańcu ${ }^{6}$. Wydaje się, że w tym nie bardzo go słuchamy. Odmawianie zdecydowanie góruje nad kontemplacją... W wielkim sanktuarium maryjnym w pierwszą sobotę miesiąca odmawiano różaniec coram Sanctissimo. Kapłan jedynie zapowiadał tajemnicę i natychmiast następowało odmawianie. Miałbym trudności z uwierzeniem, gdybym nie uczestniczył, nie widział i nie słyszał.

Ktoś zauważył w obronie odmawiania bez kontemplacji: odpusty są za odmawianie, a nie za kontemplację. Ileż to czasu trzeba by poświęcać na jedną cząstkę różańca, by zyskać odpust, gdybyśmy chcieli kontemplować wszystkie pięć tajemnic? Nawet pobożni czciciele Maryi, którzy wiernie odmawiają różaniec, mają trudności z posłuszeństwem w tym punkcie Janowi Pawłowi II. Kontemplacja w różańcu to - jak się okazuje - bardzo trudne zadanie, nawet dla maryjnej Polski i polskich sanktuariów maryjnych.

\section{DWA ZADZIWIENIA FATIMĄ}

Najpierw wstrząsający związek Fatimy z pontyfikatem Papieża Totus Tuus. To wielki znak z nieba. Od zamachu na Placu św. Piotra pontyfikat Jana Pawła II na zawsze będzie łączony z Fatimą, a więc jako wyjątkowo znaczący w dziejach Kościoła i dziejach zbawienia. Zamach i ocalenie miały miejsce w rocznicę objawień fatimskich...

Następnie - odsłonięcie trzeciej tajemnicy fatimskiej. W Fatimie w 1917 roku - jak wiadomo - Matka Boża przekazała trzy tajemnice: wizję piekła i konieczność rozpowszechnienia nabożeństwa do Niepokalanego Serca Maryi. Trzecią tajemnicę zapisaną i opieczętowaną przechowywano w tajnym archiwum Świętego Oficjum. Zapoznał się z nią papież Jan XXIII, ale postanowił jej nie ujawniać. Zapoznał się z nią także papież Paweł VI, ale również nie zdecydował się na jej ujawnienie. Jan Paweł II po zamachu na swoje życie 13 maja 1981 roku zapoznał się w trzecią tajemnicą fatimską i zdecydował o jej ogłoszeniu. Wiemy więc,

${ }^{6}$ „Różaniec [...] jest modlitwą wyraźnie kontemplacyjną. Pozbawiony tego wymiaru, okazałby się wyzuty ze swej natury, jak podkreślał Paweł VI: Jeśli brak kontemplacji, różaniec upodabnia się do ciała bez duszy i zachodzi niebezpieczeństwo, że odmawianie stanie się bezmyślnym powtarzaniem formuł oraz że będzie w sprzeczności z upomnieniem Chrystusa, który powiedział: «Na modlitwie nie bądźcie gadatliwi jak poganie» [...]”. Jan Paweł II, List apostolski Rosarium Virginis Mariae o Różańcu Świętym, 12. 
że Matka Boża żądała, by świat został oddany Jej Niepokalanemu Sercu, a jeśli to nie nastąpi, Rosja rozszerzy swoje błędy po całym świecie, wywołując wojny i prześladowania Kościoła, Ojciec święty wiele wycierpi i różne narody zginą... Jeśli spełni się żądanie Matki Bożej, Rosja nawróci się i nastanie pokój.

Jak wiemy, Jan Paweł II wielokrotnie poświęcał świat Matce Bożej. Najważniejsze poświęcenie miało miejsce 7 czerwca 1981 roku w Santa Maria Maggiore w uroczystość Zesłania Ducha Świętego. Ponowił je w Fatimie 13 maja 1982 roku i jeszcze raz ponowił na Placu św. Piotra 25 marca 1984 roku - w jedności ze wszystkimi biskupami świata. S. Łucja oświadczyła, że odpowiadało to życzeniu Matki Bożej z Fatimy.

\section{ZADZIWIENIE KATECHEZĄ O ŚMIERCI MATKI BOŻEJ ORAZ KALWARIĄ ZEBRZYDOWSKĄ}

Mamy dogmat o wniebowzięciu Matki Bożej. W konstytucji dogmatyzującej (Munificentissimus Deus, 1950) nie mówi się o śmierci Matki Najświętszej. Definicja dogmatyczna pomija tę kwestię, używając słów: „po zakończeniu ziemskiego życia”. Jakie było to zakończenie, nie rozstrzyga. Była to kwestia dyskutowana.

Tymczasem Jan Paweł II w katechezie z 25 czerwca 1997 roku wyraźnie stwierdził, że Matka Boża zmarła. Pierwszy raz w dziejach Kościoła papież tak jednoznacznie i mocno wypowiedział się za śmiercią Matki Pana ${ }^{7}$.

Może to dziwić, gdyż wielcy czciciele Matki Najświętszej na ogół nie przyjmują Jej śmierci (przecież nie miała grzechu pierworodnego, z którym wiąże się śmierć). Tymczasem Jan Paweł II, wielki czciciel Matki Bożej, mocno twierdził, że umarła.

Nasuwa się bardzo przekonywująca odpowiedź. Przecież w naszych polskich kalwariach, także w Kalwarii Zebrzydowskiej, urządza się procesję z pogrzebem Matki Bożej. Jej śmierć postrzega się jako oczywistość. Pogrzeb zakłada śmierć. Możemy zasadnie domniemywać, że kalwaryjskie pogrzeby Matki Najświętszej miały wpływ na ogólnokościelne nauczanie Jana Pawła II.

Małe dopowiedzenie. Polski franciszkanin o. Leoncjusz Jerzy Sima (+2014) przez wiele lat pracował w Turcji. Zainteresował się domkiem Matki Bożej w Meryem Ana pod Efezem. Odkrył tam żywą tradycję, według której św. Jan Apostoł, przenosząc się w tamte strony, zabrał ze sobą Matkę Najświętszą.

7 Napiórkowski, Oto Ja, Stużebnica Pana, s. 122-124. Katecheza Zaśnięcie Matki Bożej, w: JAN PAwee II, Maryja w Tajemnicy Chrystusa i Kościoła, Watykan 1998, s. 182-184. 
Tam mieszkali, tam też Matka Boża zmarła i stamtąd została wzięta do nieba. Książeczka godna polecenia. Można ją jeszcze znaleźć w Niepokalanowie. Czyta się ją jednym tchem ${ }^{8}$.

\section{CZTERY ZADZIWIENIA SPOSOBEM CZERPANIA ZE ŚW. LUDWIKA GRIGNIONA DE MONTFORT}

Powszechnie podkreśla się, że Karol Wojtyła już jako robotnik w Solvayu odkrył Traktat o doskonałym nabożeństwie do Najświętszej Maryi Panny św. Ludwika Grigniona de Montfort, że zachwycił się tym nabożeństwem streszczanym w formule Totus Tuus, że to hasło wydźwignął wysoko jako papież, wypisał je bowiem na swoim papieskim herbie i wielokrotnie ponawiał akty oddania Matce Bożej. Jest się czym zadziwiać.

Kto uważniej przypatruje się sprawie, przeżywa jeszcze trzy zadziwienia związane z interpretacją Grigniona. Otóż Jan Paweł II nie do końca akceptował jego Traktat. Pierwsze zadziwienie Wojtyłowo-Grignionowskie dotyczy argumentacji za pośrednictwem Matki Bożej. To zadziwienie zdecydowanie wchodzi w podstawowy problem, który podejmujemy. Rozwinę je więc po wyczerpaniu się bloku zadziwień mariologicznym słowem Jana Pawła II.

Jeszcze czymś innym zadziwia Jan Paweł II jako uczeń i promotor Grigniona. Zamienił Grignionowe „niewolnictwo Maryjne” na „zawierzenie Maryi”. Nie krytykował, rozumiał, nawet uzasadniał, ale jednak zmienił. A za nim zmieniła niemal cała Polska, i nie tylko ona.

Czwarte Wojtyłowo-Grignionowskie zadziwienie dotyczy interpretacji Totus Tuus. Grignion odnosi je do Matki Najświętszej: Totus Tuus, o Maria! Jan Paweł II odnosi je także do Matki Pana, ale nie tylko. Niekiedy Totus Tuus kieruje do Chrystusa czy do Ducha Świętego. Ten temat zasługuje na dokładne sprawdzenie. Nie ma wątpliwości, że w interpretacji Jana Pawła II hasło Totus Tuus otrzymuje interpretację poszerzającą.

Przykład poszerzenia chrystologicznego: 13 maja 1982 roku Jan Paweł II był w Fatimie i tam odmówił obszerny Akt oddania się Matce Bożej. Teologia tego aktu zasługuje na pogłębioną analizę, obszerniejsze studium i spopularyzowanie w Kościele?.

W pierwszej części - wyraźnie skierowanej do Maryi - ze słowami Pod Twoja obronę wspomina akt poświęcenia świata Niepokalanemu Sercu Maryi

8 J.L. Sima, Nasza Pani Efeska i jej dom w Meryem Ana, Niepokalanów 1997, s. 182.

9 Tekst tego Aktu oddania m.in. w: NAPIóRKowski, Oto Ja, Stużebnica Pana, s. 222-225. 
dokonany przed 40 latami. Druga część posiada charakter wyraźnie chrystocentryczny. Papież wskazuje na Chrystusa, który poświęca się Ojcu w ofierze za nas. Następnie podejmuje monolog do Matki Najświętszej: „Gdy dzisiaj staję przed Tobą, Matko Chrystusa, pragnę wraz z całym Kościołem, wobec Twego niepokalanego Serca, zjednoczyć się z Odkupicielem naszym w tym poświęceniu za świat i ludzkość, które tylko z Jego Boskiego Serca ma moc przebłagać i zadośćuczynić".

Dalej papież mówi, że to Jezusowe poświęcenie jest wciąż aktualne, ogarnia wszystkich ludzi i wszystkie czasy, a my pragniemy zjednoczyć się z tym poświęceniem Chrystusa. Matka Najświętsza była najpiękniej zjednoczona z tym Jezusowym odkupieńczym poświęceniem.

Papież nie mówi, że poświęcamy się Maryi, ale że poświęcamy się Chrystusowi, włączamy się w Jego poświęcenie, a Maryję mamy za wzór takiej postawy. Zdumiejcie się wszyscy teoretycy i praktycy maryjnych poświęceń i oddawania się w maryjną niewolę! Otóż Jan Paweł II kończy swój monolog zawierzeniem Maryi, ale jakżeż oryginalnym, niespotykanym u żadnego apostoła maryjnych poświęceń zawierzeniem. Papież spod znaku Totus Tuus zawierza Maryi swoje (i nasze) zawierzenie Chrystusowi: „Zawierzając Ci, o Matko, świat wszystkich ludzi i wszystkie ludy zawierzamy Ci także to nasze poświęcenie za świat, składając je w Twoim macierzyńskim Sercu".

Świat będzie mówił i pisał o fatimskim zawierzeniu Matce Bożej, zawierzeniu dokonanym przez Jana Pawła II. Czy jednak świat zauważy niezwykłość, oryginalność, głębię oraz piękno takiej teologii poświęceń? ${ }^{10}$ Zdziwiłby się nią św. Ludwik, zdziwił św. Maksymilian, ale obaj święci poszliby za naszym świętym.

\section{ZADZIWIENIE TEOLOGIĄ IKONY}

Mówimy „ikony”, a spontanicznie myślimy „prawosławie”. Według teologii prawosławnej w ikonach jest obecna przedstawiana na nich osoba, a więc ikona to niejako sakrament obecności.

W Polsce, zwłaszcza w latach peregrynacji kopii obrazu Matki Bożej Częstochowskiej, sprawa stała się bardzo aktualna. Przychodziła do parafii kopia obrazu Matki Bożej Częstochowskiej, a witaliśmy samą Matkę Bożą Częstochowską. Witaliśmy i żegnaliśmy samą Matkę Bożą, a nie tylko kopię Jej ikony. Nawet bracia prawosławni nie uznają obecności osoby w kopii jej ikony.

\footnotetext{
${ }^{10}$ Szerzej zob. NAPIóRKowski, Oto Ja, Stużebnica Pana, s. 204-205.
} 
Swoją wiarę w taką obecność wiążą jedynie z samą ikoną. A my, katolicy, właśnie w kopii i kopiach witaliśmy, czciliśmy i żegnaliśmy Matkę Bożą.

Otóż zastanowiło to kiedyś kard. Karola Wojtyłę. Witając kopię, witał Matkę Bożą. Nagle zamilkł. Zastanowił się chwilę i głośno zaczął się dziwić: jak to jest, kochani? Witamy Matkę Bożą, a przecież przychodzi tylko Jej obraz... I dalej myślał głośno: Sobór Watykański II mówi o obecności Maryi w tajemnicy Chrystusa i Kościoła. Przecież my tutaj zgromadzeni jesteśmy Kościołem. A więc Maryja jest z nami, jest pośród nas...

Zauważmy: kardynał nie wiąże obecności Matki Bożej z pielgrzymującą kopią obrazu, ale wiąże ją ze zgromadzeniem wiernych, które jest Kościołem. Nie wiąże z prawosławną teologią, ale z nauczaniem Soboru Watykańskiego II. To wielka sprawa. Wygłosiłem na ten temat referat na pewnej papieskiej uczelni w Rzymie, ale nie wydrukowano mi mojego wystąpienia, mimo że opublikowano inne materiały sesji. Trzeba, jak się zdaje, odczekać jeszcze, by to wielkie „novum” w teologii obrazów przebiło się do świadomości teologów ${ }^{11}$.

\section{ZADZIWIENIE HASŁEM PER IESUM AD MARIAM - PRZEZ JEZUSA DO MARYI}

24 września 2000 roku na Placu św. Piotra kończyliśmy Międzynarodowy Kongres Mariologiczny. Wielkiej koncelebrze przewodniczył Biskup Rzymu. On też miał homilię, którą zakończył w sposób zwykły i niezwykły, nawet niezwykle niezwykły. W sposób zwykły powiedział na zakończenie: „A więc do Jezusa przez Maryję - Ad Iesum per Mariam”. Jednak nie zamknął homilii oczekiwanym „Amen”. Podniósł oczy znad tekstu, pomilczał chwilę i dopowiedział: Ed anche per Iesum ad Mariam! - ale także przez Jezusa do Maryi!"’.

Nie przywykliśmy do tego. Przywykliśmy do „przez Maryję do Jezusa”. Do „przez Maryję do Jezusa” przyzwyczaili nas św. Ludwik Grignion de Montfort, św. O. Maksymilian, sługa boży kard. Stefan Wyszyński, również kard. Karol Wojtyła. Praktyka oddawania się w niewolę i zawierzania Maryi opiera się na idei ,przez Maryję do Jezusa”. Aż tutaj nasz maryjny papież powtarza hasło ,przez Maryję do Jezusa” i zaraz potem odwraca je na zdumiewające ,przez Jezusa do Maryi”.

${ }^{11}$ Tekst polski: S.C. NAPIÓRKowski, Maryjne ikony, które żyją na wschód od Odry, w: K. PeK, T. SiUdy (red.), W nurcie polskiej mariologii. Materiaty z sympozjum mariologicznego z okazji 50-lecia Katedry Mariologii Katolickiego Uniwersytetu Lubelskiego Jana Pawła II Lublin, 24 października 2007 roku, Częstochowa-Lublin 2008, s. 164-177. 
Niemal natychmiast zorganizowaliśmy w Polsce wielkie sympozjum na ten temat $^{12}$. Bez trudu wyjaśniliśmy, że nie chodzi o wzywanie Pana Jezusa, by wstawiał się za nami do Matki Bożej, a więc nie chodzi o wstawiennictwo, ale chodzi o coś innego, mianowicie o to, że kto wpatruje się w tajemnice Chrystusa, ten dostrzeże w nich także Matkę Bożą. Dostrzeże we właściwych proporcjach i na właściwym Jej miejscu. Przez kontemplację Jezusa otrzymujemy właściwe poznanie Jego Matki.

Usłyszeliśmy na Zachodzie, że my, Polacy, robimy burzę w szklance wody. Odmówiono mi we Włoszech publikacji artykułu na ten temat. Tymczasem ta idea nurtowała Jana Pawła II jeszcze w czasie, gdy był wikariuszem. Napisał w „Tygodniku Powszechnym”, że religijność polska, tak bardzo maryjna, potrzebuje pogłębienia, a pogłębienie przyjdzie w ślad za pogłębioną świadomością odkupienia. A więc jeszcze przed biskupstwem nosił w sobie ideę „przez Jezusa do Maryi”.

Na zakończenie uwaga bibliograficzna. Polskie Towarzystwo Mariologiczne opublikowało w Rzymie w języku włoskim książkę o mariologii Jana Pawła II z podkreśleniem jej polskich korzeni ${ }^{13}$. Taka książka to wydarzenie.

\section{ZADZIWIENIE POŁĄCZENIEM „JEZU, UFAM TOBIE!” Z MARYJNOŚCIĄ}

Również to „Zadziwienie” przesuwamy do drugiej części referatu ze względu na bliski związek z tematem.

\section{DWA ZADZIWIENIA O. MAKSYMILIANEM}

Pierwsze zadziwienie - chrystologiczna interpretacja życia św. Maksymiliana. Dość powszechnie ukazuje się o. Maksymiliana jako wielkiego apostoła Niepokalanej Wszechpośredniczki, misjonarza, człowieka mediów, odnowi-

\footnotetext{
${ }^{12}$ S.C. NAPIórkowski, w: S.C. NAPIóRKowski, K. Pek (red.), Przez Jezusa do Maryi. Materiaty z sympozjum mariologicznego zorganizowanego przez Polskie Towarzystwo Mariologiczne, Licheń, 26-27 października 2001 roku, Częstochowa-Licheń 2002.

${ }^{13}$ Polskie Towarzystwo Mariologiczne, Assoziazione Mariologia Polacca, La Vergine Maria nel magistero di Giovanni Paolo II, red. T. Siudy, tł. L. Abignente, Città del Vaticano 2007. W książce nie ma ani tekstu o Per Iesum ad Mariam, ani tekstu o polskiej interpretacji obecności Matki Bożej w obrazach, chociaż polscy autorzy przygotowali takie artykuły. Zob. także: B. Kochaniewicz, Wybrane zagadnienia z mariologii Jana Pawta II, Niepokalanów 2007; NAPIóRKowsKi, PeK (red.), Mariologia Jana Pawta II.
} 
ciela charyzmatu franciszkańskiego. Jan Paweł II dostrzegł w nim zdecydowanie rzadziej przypominany szczegół, mianowicie podobieństwo do Chrystusa, który życie swoje oddał, by ocalić skazanych. W homilii na polach Niepokalanowa 18 czerwca 1983 roku nieprzeliczone rzesze posłyszały m.in. takie słowa:

Maksymilian Kolbe przez swoją śmierć w obozie koncentracyjnym, w bunkrze głodowym, potwierdził w jakiś szczególnie wymowny sposób dramat ludzkości dwudziestego stulecia. Jednakże motywem głębszym i właściwym wydaje się to, że w tym kapłanie-męczenniku w jakiś szczególny sposób przejrzysta stała się centralna prawda Ewangelii: prawda o potędze miłości. „Nie ma większej miłości od tej, gdy kto życie oddaje za przyjaciół swoich" (J 15,13) - tak mówi Jezus, żegnając się z apostołami w wieczerniku, zanim pójdzie na mękę i śmierć. „Przeszliśmy ze śmierci do życia, bo miłujemy braci" - powtórzy za swoim Mistrzem Jan apostoł w pierwszym swoim Liście $(3,14)$. I zakonkluduje: „Po tym poznaliśmy miłość, że On oddał za nas życie swoje. My także winniśmy oddać życie za braci” $(3,16)^{14}$.

O. Maksymilian według Jana Pawła II to przede wszystkim heros miłości: jak Chrystus oddał życie, by ocalić życie innego człowieka.

Zauważcie zwłaszcza wy, niepokalanowianie! Papieżu nas, w Niepokalanowie, podkreśla w naszym Założycielu przede wszystkim nie miłość do Niepokalanej, a jego heroiczną miłość bliźniego!

Drugie zadziwienie. Dwie korony: biała i czerwona. Małemu Rajmundowi Kolbe Matka Boża zaproponowała koronę białą albo czerwoną. Rajmund wyciągnął ręce po obie. Papież Paweł VI w 1971 roku beatyfikował o. Maksymiliana Rajmunda Kolbe jako wyznawcę, czyli ukoronował go koroną białą. Jan Paweł II w 1982 roku kanonizował go jako męczennika, czyli ukoronował go koroną czerwoną. Czy to nie godne podziwu! Czy w dwutysięcznych dziejach Kościoła zdarzył się drugi taki przypadek dwu koron: białej i czerwonej?

Niechaj nasze zadziwienia wypięknią i pogłębią nasz zachwyt Matką Pana.

Niech wzbudzą zasłużony podziw także dla Jana Pawła II w jego słowie o Maryi.

Niech dodadzą nam skrzydeł do wyższych i jeszcze wyższych lotów naszej pobożności.

${ }^{14}$ Homilia Ojca Świętego podczas Mszy Świętej dziękczynnej (Niepokalanów 18 czerwca 1983 r.), „Rycerz Niepokalanej”, (1983), nr 8(326), s. 232. 


\section{MARIOLOGIA I MARYJNOŚĆ A MILOSIERDZIE BOGA OJCA, CHRYSTUSA I MARYI}

Grignion ma w Traktacie obszerny fragment, w którym kontrastuje obraz Boga Ojca i Chrystusa z obrazem Maryi, przy czym Maryja wychodzi korzystniej w ocenie grzesznego człowieka. Majestat i świętość Chrystusa oraz gniew Boga Ojca odstraszają człowieka, a w Maryi tego nie ma. Dlatego potrzebujemy pośrednictwa Maryi i trzeba przez Nią do Nich. Św. Ludwik powołuje się tu na św. Bernarda i św. Bernardyna ze Sieny. Koniecznie trzeba zauważyć ten sposób zalecania pośrednictwa Maryi oraz oddawania się Jej w niewolę, ponieważ takie myślenie powtarza się bezkrytycznie w mnóstwie publikacji.

W czwartym rozdziale części drugiej Traktatu święty autor pisze o Chrystusie jako pośredniku. Bez Jego zasług nie mamy przystępu do Ojca. Niemniej pośrednictwo Chrystusa ma swoje „ale”: przecież Chrystus także jest pełen majestatu, jest święty, jest Bogiem równym Ojcu i trzeba się lękać Jego majestatu oraz świętości. Dlatego - jak pisze św. Ludwik - potrzebujemy pośrednika do takiego Pośrednika. Matka Najświętsza jest doskonałą pośredniczką do Pośrednika, nikogo nie odpycha (tak jakby Pan Jezus odpychał!) itd. Taką teologią św. Ludwik zdaje się kwestionować naszą bezpośredniość ze Zbawicielem, zniekształcać Jego obraz... Koniecznie trzeba zwrócić uwagę na ten tekst Grigniona, cały rozdział czwarty części drugiej. Bardzo, a bardzo ważki tekst dla problemu podejmowanego w naszym środowisku teologicznym.

Potrzeba nam pośrednika u istotnego Pośrednika, jakim jest Jezus Chrystus ${ }^{15}$. Rzeczą bardziej doskonałą, bo nacechowaną większą pokorą, jest nie podchodzić do Pana Boga wprost, lecz przy pomocy pośrednika. Ponieważ, jak to wykazaliśmy poprzednio, istota nasza jest tak skażona, że jeśli w naszym dążeniu do Boga i w chęciach przypodobania się Mu polegać będziemy wyłącznie na własnych wysiłkach, ćwiczeniach i przygotowaniach, nie ulega wątpliwości, iż wszystkie osiągnięcia nasze będą skalane lub nieważne w oczach Boga i niezdolne skłonić Go do połączenia się z nami i wysłuchania nas. Nie bez powodu bowiem dał nam Bóg pośredników u Swego Majestatu. Ujrzał On naszą niegodność i niezdolność, a ulitowawszy się nad nami, zaopatrzył nas w orędowników możnych przed Obliczem Jego. Pomijać tych pośredników i zbliżać się do Jego świętości wprost i bez niczyjego poparcia znaczy uchybiać pokorze i szacunkowi należnemu Bogu tak świętemu i wielmożnemu. Znaczy to okazywać temu Królowi królów mniej względów niżeli jakiemukol-

${ }^{15}$ Tekst z książki: L.M. Grignion De Montfort, Traktat o prawdziwym nabożeństwie do Najświętszej Marii Panny, tł. J. Rybałt, Niepokalanów 1948, s. 72-74. 
wiek królowi czy księciu ziemskiemu, do którego nie ośmielilibyśmy się zbliżyć bez przyjaciela, który by się za nami wstawił. Chrystus Pan jest naszym Rzecznikiem u Boga Ojca i Pośrednikiem w dziele Odkupienia. Przez Niego mamy się modlić wraz z całym Kościołem triumfującym i wojującym. Przez Niego mamy przystęp do Majestatu Bożego i nie powinniśmy nigdy ukazywać się przed Obliczem Pana inaczej jak wsparci na zasługach Chrystusowych i przyobleczeni w nie na podobieństwo małego Jakuba, odzianego w koźlą skórę, gdy stawi się przed Izaakiem, by otrzymać jego błogosławieństwo. Czyż jednak nie potrzebujemy pośrednika do samego Pośrednika? Azali czystość nasza jest dość wielka, abyśmy się wprost i bezpośrednio z Nim połączyć mogli? Azali nie jest On Bogiem, we wszystkim Ojcu równym, a więc Świętym świętych, na równi z Ojcem godnym szacunku? Jeśli z nieskończonego miłosierdzia Swego stał się naszym zakładnikiem i pośrednikiem u Boga, Ojca Swego, by uśmierzyć gniew Jego i spłacić Mu nasz dług, czyż mielibyśmy dlatego mniej Go szanować i mniej lękać się Jego Majestatu i świętości? Powiedzmy więc śmiało ze św. Bernardynem ${ }^{16}$, że potrzeba nam pośrednika u samego Pośrednika, a Najśw. Panna najlepiej zdoła spełnić ten miłosierny urząd. Przez Nią Chrystus przyszedł do nas i przez Nią również my do Niego dojść mamy. Skoro boimy się iść wprost do Jezusa Chrystusa, Boga naszego, z powodu naszej nikczemności czy grzechów, wzywajmy śmiało pomocy i wstawiennictwa Marii, naszej Matki. Ona jest dobra i czuła, nie ma w Niej nic surowego ni odstraszającego, nic zbyt wzniosłego lub olśniewającego. Patrząc na Nią nie widzimy nic innego jeno własną naturę naszą w stanie nieskażonym. Nie jest Ona słońcem, które by blaskiem swych promieni mogło oślepić naszą ułomność, ale jest piękna i łagodna, jak księżyc, który światło swe otrzymuje od słońca i łagodzi, by dostosować je do naszych ograniczonych źrenic. Jest Ona tak miłosierna, iż nigdy nie odpycha nikogo, kto Ją o wstawiennictwo błaga, choćby był najcięższym grzesznikiem. Albowiem, jak zapewniają nas Święci, jeszcze nigdy nie słyszano, od czasu jak świat światem, by ktokolwiek uciekający się do Najśw. Dziewicy z ufnością i wytrwałością, od Niej został opuszczony. Jest Ona tak można, iż nigdy jeszcze żadna Jej prośba odrzucona nie została. Wystarczy, aby stanęła przed swym Synem, a prośba Jej natychmiast wysłuchana bywa. Bóg ulega Swej miłości do Tej, której wnętrzności Go nosiły, a piersi wykarmiły, i nie zdoła oprzeć się prośbom Swej ukochanej Matki. Wszystko, cośmy wyżej wypowiedzieli, zaczerpnęliśmy z pism św. Bernarda i św. Bonawentury. Według nich winniśmy po trzech stopniach wstępować do Boga. Pierwszy, najbliższy nam i najdostępniejszy dla nas - to Maria, drugim jest Chrystus, a trzecim Bóg Ojciec. By dojść do Jezusa, trzeba iść do Marii, bo Ona jest naszą Pośredniczką

${ }^{16}$ Powinno być „Bernardem”. 
w orędownictwie. By dojść do Ojca Przedwiecznego, trzeba iść do Jezusa, gdyż jest On naszym Pośrednikiem w dziele Odkupienia. Otóż, nabożeństwo, o którym teraz mówić będę, umożliwi nam ścisłe zachowanie powyższego porządku.

Podczas kolokwium habilitacyjnego habilitant proponuje pięć tematów wykładu habilitacyjnego. Rada Wydziału wybiera jeden. Ks. dr Kazimierz Pek na swoim kolokwium zaproponował Radzie Wydziału jako ostatni, piąty: „Św. Ludwik Grignion de Montfort przeceniony mariolog, niedoceniony teolog”. Po chwili zdumionego milczenia Rada Wydziału zgodnie zażyczyła sobie tegoż wykładu o Montforcie. Opublikowanie wszystkim dzieł Grigniona ukazało go jako dobrego teologa, tymczasem jako teolog jest on mało znany. Przypomina się go jako mariologa, niestety, na ogół bezkrytycznie. Mówi się o ok. tysiącu wydań w wielu językach jego mariologicznego Traktatu. Zdecydowanie ukształtował on w Kościele katolickim myślenie i nauczanie o modlitwie prośby. Z entuzjazmem to nauczanie św. Ludwika powtarza św Maksymilian.

Interesujące, że ani św. Ludwik, ani św. Maksymilian nie sięgają przy tym temacie do katechezy Pana Jezusa, dość wyraźnie innej. Jezus uczył: „O cokolwiek prosić będziecie w imię moje, to uczynię, aby Ojciec był otoczony chwałą w Synu. O cokolwiek prosić Mnie będziecie w imię moje, Ja to spełnię" (J 14,13); „Kto do Mnie przychodzi, nie będzie łaknął; a kto we mnie wierzy, nigdy pragnąć nie będzie [...]. Wszystko, co mi daje Ojciec, do mnie przyjdzie, a tego, kto do mnie przychodzi, precz nie odrzucę” (J 3,35.37); „Przyjdźcie do mnie wszyscy, którzy utrudzeni i obciążeni jesteście, a ja was pokrzepię" (Mt 11,28); „Nie wyście mnie wybrali, ale a was wybrałem i przeznaczyłem was na to, abyście szli i owoc przynosili i by owoc wasz trwał - aby wszystko dał wam Ojciec, o cokolwiek Go poprosicie w imię moje” (J 15,16); „Zaprawdę, zaprawdę powiadam wam: o cokolwiek byście prosili Ojca, da wam w imię moje. Do tej pory o nic nie prosiliście w imię moje. Proście a otrzymacie, aby radość wasza była pełna" (J 16,23).

Zdumiewające: nigdzie w pismach Wojtyły, księdza, biskupa, kardynała i papieża nie znalazłem Grignionowskiej argumentacji za pośrednictwem Matki Bożej i za tzw. prawdziwym nabożeństwem z implikowaną tam teologią sprawiedliwości i miłosierdzia. Nie krytykował, ale nie powtarzał, nie przejmował, nie promował, nie przekazywał dalej. Chwała temu naszemu świętemu za jego niewierność tamtemu świętemu w takim - powiedzmy to wyraźnie - niefortunnym, nieudanym fragmencie mariologii oraz maryjności. 
Sprawdziłem pod tym kątem encyklikę Redemptoris Mater ${ }^{17}$. Część III pt. Pośrednictwo macierzyńskie wyraźnie wciągała do lektury. Jeśli gdzieś, to tutaj znaleźć powinniśmy słowo na pasjonujący nas temat. Sprawdziłem i nie znalazłem. Papież konsekwentnie wykłada mariologię i maryjność Vaticanum II. Nigdzie nie pojawia się z Grignionem. Jan Paweł II podarował Kościołowi encyklikę o Bożym Miłosierdziu Dives in misericordia ${ }^{18}$.

\section{JEZU, UFAM TOBIE}

Ojciec Święty wyniósł na ołtarze s. Faustynę i zdecydowanie promował kult miłosierdzia Bożego z, Jezu, ufam Tobie!”. Tylko pozornie nie ma to znaczenia dla maryjnej pobożności i dla mariologii. Wystarczy przejrzeć nasze śpiewniki i modlitewniki, by stwierdzić, jak często i mocno przeciwstawia się tam miłosierdzie Matki Bożej sprawiedliwości Chrystusa i sprawiedliwości Boga Ojca. Niekiedy wydaje się, że nie pozostaje nam nic innego, jak uciekać od Nich do Niej, by nas ratowała przed Nimi...

Tymczasem objawienia miłosierdzia Bożego i „Jezu, ufam Tobie!” apelują, by Matkę Bożą postrzegać jako najpiękniejszy owoc miłosierdzia Bożego i jako tę, która pomaga Bogu i swojemu Synowi okazywać Ich miłosierdzie. Czy lub w jakiej mierze tradycyjna modlitwa różańcowa uwzględnia teologię i duchowość „Jezu, ufam Tobie”? Często przewodniczymy modlitwie różańcowej. Czy uwzględniamy w niej niesłychanie doniosłe znaczenie objawień „Jezu, ufam Tobie”? Czy nie należy „Jezu, ufam Tobie” uwzględniać także w modlitwie różańcowej? Jeśli tak, jak to czynić? A może nie powinno się „Jezu, ufam Tobie” uwzględniać w Różańcu?

To temat na wiele sympozjów. Tutaj niech wystarczy prosty sygnał i zadziwienie. W pielgrzymowaniu do światła w tej przestrzeni może warto zauważyć prace dyplomowe z mariologii Jana Pawła II opracowane i obronione w Katedrze Mariologii w latach 1980-2005: dwie doktorskie Siwaka

\footnotetext{
${ }^{17}$ JAN PAweŁ II, Encyklika Redemptoris Mater o Błogosławionej Maryi Dziewicy w życiu pielgrzymującego Kościoła, w: Matka Odkupiciela Matka Kościoła. Dokumenty, Warszawa 1990, s. 301-351. JAN PAWEe II, Matka Odkupiciela. Tekst i komentarze, red. S.C. NAPIIÓRKowsKI, Lublin 1993. „Ateneum Kapłańskie” poświęciło encyklice Redemptoris Mater nr 110 (1988), z. 3 (komentarze, bez tekstu encykliki).

18 Jan Pawę II, Encyklika Dives in misericordia o Bożym miłosierdziu, w: Encykliki Ojca Swiętego Jana Pawła II, Kraków 1996, s. 77-139. Encyklika została wydana 30 listopada 1980 roku, w pierwszą niedzielę Adwentu, w trzecim roku pontyfikatu.
} 
i Orczyka i trzydzieści kilka magisterskich ${ }^{19}$. Olbrzymie hasło w Encyklopedii katolickiej - „JAN PAWEL II, Karol Wojtyła” ${ }^{20}$ nie zauważa naszego problemu. Miłosierdzie łączy z miłosiernym Ojcem i z Duchem Pocieszycielem ${ }^{21}$. W haśle „Miłosierdzie Boże” sporo uwagi poświęca objawieniom s. Faustyny $\mathrm{z}$,Jezu, ufam Tobie”, ale ani słowem nie wiąże tego z Matką Bożą, tym bardziej z różańcem ${ }^{22}$.

\section{BIBLIOGRAFIA S.C. NAPIÓRKOWSKIEGO NA TEMAT MARIOLOGII ORAZ MARYJNOŚCI JANA PAWŁA II}

Prawostawna teologia ikony w katolickiej Polsce?, „Summarium”, (1980), nr 9, s. 125-129. Odnowa kultu maryjnego. Stwierdzenia - Problemy otwarte - Sprawy oczekujace na interwencje (podsumowanie sympozjum), „Teologia w Polsce”, 4(1986), nr 9, s. $35-42$.

Mariologiczna Adhortacja Pawła VI i mariologiczna Encyklika Jana Pawła II w stużbie odnowy kultu maryjnego, „Teologia w Polsce”, (1987), nr 13, s. 26-33.

Ku odnowie kultu maryjnego, „Ateneum Kapłańskie”, 110(1988), s. 416-429.

L'enciclica di Giovanni Paolo II , Redemptoris Mater”. Un messagio alla Chiesa di Polonia (Lublin, 9 maggio 1988), „Marianum” 50(1988), z. 1-2, s. 559-560.

Adhortacja Pawła VI ,Marialis cultus” i encyklika Jana Pawła II ,Redemptoris Mater" w odnowie kultu maryjnego, w: S.C. NAPIÓRKOwSKI (red.), , Btogosławić mnie będa”. Adhortacja Pawła VI „Marialis cultus”. Tekst - komentarze - dyskusja, Lublin 1990, s. 73-81.

Polska teologia ikony? Problem obecności Maryi pośród nas w świetle doświadczeń peregrynacji, „Teologia w Polsce”, 8(1990), nr 24, s. 3-4.

Encyklika Jana Pawła II Redemptoris Mater. Zagadnienia wybrane, w: K. MACHETA, K. GóźDź, M. KowalczyK (red.), Historia i Logos, Lublin 1991, s. 101-115.

Matka naszego Pana (problemy - poszukiwania - perspektywy), Tarnów 1992.

Pośrednictwo do Chrystusa, w Chrystusie, w Duchu Świętym, w: R. Deyna (red.), Kapituła Duchowa Prowincji, Gdańsk 1992, s. 149-154.

${ }^{19}$ Wykaz niżej.

${ }^{20}$ Autor nie zauważa naszego problemu. Miłosierdzie łączy z Miłosiernym Ojcem i z Duchem Pocieszycielem. J. Bajda, J. Merecki, T. Styczeń, Jan Pawel II, Karol Wojtyła, w: J. Duchniewski (red.), Encyklopedia katolicka, t. VII, s. 858.

${ }^{21}$ Jan Pawel II, Karol Wojtyła, s. 858.

${ }^{22}$ Miłosierdzie Boże, w: Encyklopedia katolicka, t. XII, s. 1088-1115 (najważniejszy fragment: Kult M.B.). 
Encyklika Jana Pawła II „,Redemptoris Mater”. Zagadnienia wybrane, w: S.C. NAPIóRKowsKi (red.), Matka naszego Pana, Tarnów 1992, s. 167-180.

Przodująca $w$ wierze, w: S.C. NAPIÓRKowsKi (red.), Matka naszego Pana, Tarnów 1992, s. 212-222.

Redemptoris Mater - Lumen gentium - Marialis cultus, w: S.C. NAPIÓRKowsKi (red.), Matka naszego Pana, Tarnów 1992, s. 181-195.

Macierzyńskie pośrednictwo w Duchu Świętym, w: S.C. NAPIóRKowsKi (red.), Jan Pawet II. Matka Odkupiciela. Tekst i komentarze, Lublin 1993, s. 215-245 (z T. Wilskim).

Nie ma dobrej mariologii bez dobrej teologii, w: S.C. NAPIóRKowsKi (red.), Jan Pawet II. Matka Odkupiciela. Tekst i komentarze, Lublin 1993, s. 129-132.

O mariologii eklezjotypicznej, w: J.S. GAJEK, K. PeK (red.), Matka Jezusa pośród pielgrzymującego Kościoła, Warszawa 1993, s. 19-36.

Pośredniczka w Chrystusie, w: S.C. NAPIÓRKowski (red.), Jan Paweł II. Matka Odkupiciela. Tekst i komentarze, Lublin 1993, s. 195-213.

Wprowadzenie, w: S.C. NAPIóRKowski (red.), Jan Pawet II. Matka Odkupiciela. Tekst i komentarze, Lublin 1993, s. 67-69.

Znacznie Mühlena dla współczesnej mariologii. Pastoralne znaczenie nauki o pośrednictwie w Duchu Świętym, w: S.C. NAPIóRKowski (red.), O Maryi dziś ze św. Maksymilianem, Niepokalanów 1993, s. 136-139.

O piaty dogmat maryjny, „Teologia w Polsce”, 13(1995), nr 42, s. 46-48.

„,Redemptoris Mater” - „Lumen gentium”-, Marialis cultus”, w: In Te Domine speravi. Księga pamiątkowa poświęcona Księdzu Arcybiskupowi Bolesławowi Pylakowi Metropolicie Lubelskiemu, Lublin 1996, s. 173-185.

O Maryi nigdy dość, ale poprawnie. Z O. Stanisławem Celestynem Napiórkowskim rozmawiają Elżbieta Adamiak i Monika Waluś, w: Z. Nosowski (red.), Dzieci Soboru zadaja pytania. Rozmowy o Soborze Watykańskim II, Warszawa 1996, s. 91-112. Zawierzenie chrześcijanina, „Z Niepokalaną”, (1996), nr 2(6), s. 12-13.

Czego nas nauczył Papież, „Życie”, (1997), VI.

Czy Matka Boska umarta?, ,Tygodnik Powszechny”, (1997), nr 28, s. 11.

Jubileuszowe oceny Soboru Efeskiego: Pius XI (1931 r.) - Jan Pawet II (1981 r.), w: S.C. NAPIóRKowski, S. Longosz (red.), Maryja w Tajemnicy Chrystusa, Niepokalanów 1997, s. 100-103.

W rocznice Soboru Efeskiego, w: S.C. NAPIÓRKowski, S. Longosz (red.), Maryja w Tajemnicy Chrystusa, Niepokalanów 1997, s. 317-325

NAPIÓRKowsKi S.C., Longosz S. (red.), Maryja w Tajemnicy Chrystusa, Niepokalanów 1997. 
Wielcy chrześcijanie wobec Tajemnicy Bożego Macierzyństwa. Wybór tekstów, w: S.C. Napiórkowski, S. Longosz (red.), Maryja w Tajemnicy Chrystusa, Niepokalanów 1997, 312-325.

L'esperienza storica delle persone e delle communità cristiane come fonte di teologia. La mariologia kolbiana e la „Redemptionis Mater”, w: E. Galignano (red.), San Massimiliano Kolbe e la Nuova Evangelizzazione. Atti del Congresso Internazionale (Niepokalanów, Polonia, 19-25 Settembre 1994), Roma 1999, s. 333-347.

Ocena rozprawy doktorskiej mgr lic. Beaty Bilickiej „Katecheza mariologiczna Jana Pawta II”, (Olsztyn 1999, WT, 210 s.), napisanej w indywidualnym toku studiów na seminarium Historii Dogmatów Biskupa Prof. Dr Hab. Juliana Wojtkowskiego, „Teologia w Polsce”, 17(1999), nr 59, s. 6-8.

Nieobliczalność Bożego Ducha, „Pastores”, (2000), nr 8, s. 156-158.

O mariologie w kontekście, w: K. PeK (red.), Per Spiritum ad Mariam. Implikacje mariologiczne pneumatologii, Lublin 2000, s. 15.

Per Iesum ad Mariam. Głos $w$ dyskusji po referacie ks. K. Peka o Kongresie Mariologicznym w Rzymie, w: L. BALTER, P.M. LenART (red.), Mariologia na przełomie wieków. Materiały z sympozjum zorganizowanego przez Polskie Towarzystwo Mariologiczne, Niepokalanów, 27-28 października 2000 roku, Częstochowa - Niepokalanów 2001, s. 39-40.

Dogmat o wniebowzięciu w 50. rocznicę ogłoszenia, w: L. BALTER, P.M. LenART (red.), Mariologia na przełomie wieków. Materiały z sympozjum zorganizowanego przez Polskie Towarzystwo Mariologiczne, Niepokalanów, 27-28 października 2000 roku, Częstochowa-Niepokalanów 2001, s. 95-115.

Fatima a Rosja. Modele doświadczenia z tematem, w: L. BALter, P.M. LenART (red.), Mariologia na przełomie wieków. Materiały z sympozjum zorganizowanego przez Polskie Towarzystwo Mariologiczne, Niepokalanów, 27-28 października 2000 roku, Częstochowa-Niepokalanów 2001, s. 169-176.

SiwAK W., Fiat mihi secundum verbum. Maryja w Tajemnicy Wcielenia wedtug Jana Pawła II, Lublin 2001 (seria: Mariologia w kontekście 2).

Per Iesum ad Mariam. Interpretacja wypowiedzi Jana Pawła II, w: S.C. NAPIÓRKowsKI, K. PeK (red.), Przez Jezusa do Maryi. Materiaty z sympozjum mariologicznego zorganizowanego przez Polskie Towarzystwo Mariologiczne. Licheń, 26-27 października 2001 roku, Częstochowa-Licheń 2002, s. 9-29.

Napiórkowski S.C., Pek K. (red.), Przez Jezusa do Maryi. Materiaty z sympozjum mariologicznego zorganizowanego przez Polskie Towarzystwo Mariologiczne. Licheń, 26-27 października 2001 roku, Częstochowa-Licheń 2002,.

Pierwsza Chrześcijanka i Przewodniczka Ludu pielgrzymujacego, w: W. SiAK (red.), Kościół czci Matkę swego Pana. Sympozjum mariologiczne zorganizowane przez 
Wyższe Seminarium Duchowne w Przemyślu w dniu 23 października 2003 r., Przemyśl 2003, s. 137-148; to samo w: Podpora R. (red.), Archidiecezjalny Kongres Różańcowy, Wąwolnica, 17-18 czerwca 2000, Lublin 2000, s. 55-69.

Rozmowa z o. prof. Stanisławem Celestynem Napiórkowskim OFMConv. Problem pobożności maryjnej to problem relacji do Chrystusa, „Homo Dei”, 73(2003), nr 2, s. 141-157.

Jak uprawiać mariologię?, w: Kościół w życiu publicznym. Teologia polska i europejska wobec nowych wyzwań, t. II, Lublin 2004, s. 105-110; przedruk w: S.C. NAPIóRKowski, Oto Ja, Stużebnica Pana (problemy-poszukiwania-perspektywy), Lublin 2015, s. 221-236.

Maryja a Eucharystia wedtug encykliki „Ecclesia de Eucharistia”, w: W. Nowak (red.), Misterium Eucharystii. Teologia - liturgia - ekumenizm. Encyklika Jana Pawła II „Ecclesia de Eucharistia”, Olsztyn 2004, s. 197-213.

Wstęp do encykliki Redemptoris Mater, w: JAN PAWEŁ II, Dzieła zebrane, t. I: Encykliki, Kraków 2006, s. 229-231.

Doświadczenie i objawienia. Wspótmyśląc z Janem Pawłem II, w: S.C. NAPIóRKowsKI, K. PeK (red.), Mariologia Jana Pawła II. Problem interpretacji - sposób recepcji, Lublin 2007, s. 29-46; przedruk w: S.C. NAPIóRKowsKi, Oto Ja, Stużebnica Pana (problemy-poszukiwania - perspektywy), Lublin 2015, s. 203-218.

Napiórkowski S.C., Pek K. (red.), Mariologia Jana Pawła II. Problem interpretacjisposób recepcji, Lublin 2007.

Mariologia Jana Pawła II, rec. B. KochaniEwICZ, Wybrane zagadnienia z mariologii Jana Pawła II, Niepokalanów 2007, ss. 180.

Maryjne ikony, które żyją na wschód od Odry, w: K. PEK, T. SIUDY, W nurcie polskiej mariologii. Materiaty z sympozjum mariologicznego z okazji 50-lecia Katedry Mariologii Katolickiego Uniwersytetu Lubelskiego Jana Pawła II, Lublin, 24 października 2007 roku, Biblioteka Mariologiczna 11, Częstochowa-Lublin 2008, s. 164-179.

Icone mariane vivono all'est dell'Oder, „Studia Oecumenica”, 8(2008), s. 105-120.

Ad Mariam per Iesum. Interpretacja wypowiedzi Jana Pawła II, „Lignum Vitae”, 11(2010), s. 11-125.

W mariologicznej szkole Jana Pawła II, „Lignum Vitae”, 11(2010), s. 403-411.54. Bibliografia S. C. Napiórkowskiego na temat Jana Pawła II (układ chronologiczny), „Lignum Vitae”, 11(2010), s. 413-418.

Mariologia Jana Pawła II, rec. B. KochanIEWICz, Wybrane zagadnienia z mariologii Jana Pawła II, Niepokalanów 2007, „Lignum Vitae”, 11(2010), s. 449-453.

Polacy interpretuja mariologie Jana Pawła II dla Zachodu, rec. Polskie Towarzystwo Mariologiczne, Associazione Mariologia Polacca, T. SiUdy (red.), La Ver- 
gine Maria nel magistero Paolo II, Città del Vaticano 2007, „Lignum Vitae”, 11(2010), s. 453-457.

Maryja nie potrzebuje fatszywej czci, „Pastores”, (2011), nr 50, s. 69-79; to samo, lecz w skrócie: „Biuletyn Katedra Mariologii KUL. Dokumenty Studia Ogłoszenie”, (2011), nr specjalny, s. 1-7.

Duch Święty nasz Orędownik?, „Roczniki Teologii Dogmatycznej”, 5(2013), s. 15-26. Z Matka Pana w Kazachstanie, Lublin 2019.

Matka. Problemy poszukiwania perspektywy, Lublin 2019.

Opera minora, czyli okruchy ze stołu teologa, Lublin 2019.

14. MIŁOSIERDZIE. BIBLIOGRAFIA UZUPEŁNIAJĄCA

Bernyś M., Jan Paweł II i Siostra Faustyna. Potęga Bożego Miłosierdzia, Ząbki 2011. GóRny J.J. (oprac.), Bóg bogaty $w$ miłosierdzie. VIII pielgrzymka Jana Pawła II do ojczyzny, Olsztyn 2002.

Kanonizacja pierwszej Polski s. M. Maustyny Kowalskiej ze Zgromadzenia Matki Bożej Miłosierdzia, „Orędzie Miłosierdzia”, (2000).

KuźNIK K. (red.), Myśli różańcowe, t. I, Marki 1999.

NAPiórkowski A.A., WARchol P., Czy św. Faustyna i św. Jan Pawet II zostana doktorami Kościoła? Polscy święci apostołami Bożego Miłosierdzia, Niepokalanów 2014.

Napiórkowski A.A., Warchol P., Kościót Miłosierdzia, Niepokalanów 2016.

Отто-Weissowa W. (red.), Tajemnica Bożego Miłosierdzia, Kazania, Kraków 2002.

RzePniewski M., Różaniec. Rozważania Różańcowe razem z Tajemnicami Światła uzupetnione o Różaniec Śpiewany, Marki 2003.

SznURKowski S. (oprac.), Różaniec z błogostawiona siostrą Faustyną, Częstochowa 1997.

Zakopiańskie Medytacje Różańcowe, Ząbki 2001.

Cholewa M., Drzyżdżyk Sz., Gilski M. (red.), Zrozumieć, aby czcić. Encykliki Jana Pawła II, Kraków 2014. 


\section{JAN PAWEŁ II JAKO NAUCZYCIEL MARIOLOGII I MARYJNOŚCI}

S T R E S Z C Z E N I E

Zgodnie z metodologiczną zasadą poprawna interpretacja Jana Pawła II (nie tylko zresztą jego) postuluje uwzględnianie szerszego kontekstu jego wypowiedzi. W prezentacji mariologii i maryjności papieża koncentruję się na tym, co budzi mniejsze czy większe zadziwienia. Jan Paweł II korzystał z Traktatu św. Ludwika Grigniona de Montfort. Nigdy z nim nie polemizował, nigdy go nie krytykował, ale nie wszystko przejmował. Jan Paweł II konsekwentnie wykłada mariologię Vaticanum II, a nie mariologię Grigniona. Zdecydowanie promuje modlitwę różańcową, m.in. w Rosarium Virginis Mariae, ale apeluje o kontemplację przypominanych w nim misteriów naszej wiary. Apeluje i prosi, by nie poprzestawać na samym odmawianiu różańca.

Słowa kluczowe: chrystologia; mariologia; Jan Paweł II. 